\title{
Editorial
}

\section{About the Journal}

The Brazilian Journal of Computers in Education - RBIE (ISSN: 1414-5685; online: 2317-6121), founded in 1997, is a peer-reviewed academic publication maintained by the Special Committee on Computers in Education (Comissão Especial de Informática na Educação CEIE) of the Brazilian Computer Society (Sociedade Brasileira de Computação - SBC) in partnership with researchers and universities from Brazil and abroad.

The RBIE journal follows strict quality control standards to ensure the publication of scientific manuscripts of excellence in the area of Computers in Education. It aims to disseminate tools, methods and practices that help in the effective use of technology in the teaching and learning process.

\section{The Year of 2016}

Throughout 2016, a number of improvements were made in RBIE. The content of the journal Web site was fully revised and reformulated. A change worth mentioning from the start is the new default language of the Web site. Although it is still possible to select Portuguese or Spanish, English is now the default language. To promote such change it was necessary to update all metadata from the previous published articles in RBIE. This apparently small action is an attempt to increase the visibility of RBIE internationally and attract new researches from other communities.

New indexing initiatives:

- Qualis: Analysis and report of the Qualis indices from different areas (e.g., Computer Science, Education, Teaching and Interdisciplinary) with regards to possible deviations during the RBIE evaluation.

- BDBComp: Metadata from articles published between 2009 and 2016 in the BDBComp were gathered and uploaded. The current status of this process is: awaiting for indexing services.

- Scielo: A number of actions have been performed to prepare RBIE to be indexed by Scielo. There is still some work to be done in order to increase our chances to succeed. The editors are working hard to make it possible and increase the visibility and impact of RBIE in the near future.

- ACM: An attempt to index RBIE at the ACM Digital Library was performed by the editors. However, although there is a possibility to index RBIE in ACM DL, it would require the indexation of all SBC journals. Unfortunately, as mentioned by the SBC directors, such indexation might not occur as other SBC journals works with different publishers.

A number of issues were detected and corrected on the RBIE formatting guidelines, considering the authors' and editors' points of view. Now, new formatting guidelines and templates are available on the RBIE Web site. In addition, more detailed instructions and supporting material were developed to help the authors in writing good articles to RBIE. A new 
template for the articles was developed, including a latex template, which was a long standing demand of the Journal.

The list of reviewers and their information (e.g. research interests, new affiliations, etc.) were revised and updated in order to speed up the evaluation process and help to better allocate the manuscripts.

The reviewing forms are being updated as a result of editors discussion and experience with the obtained reviews throughout 2016. Hopefully the changes performed will help reviewers on providing better feedback to the authors.

Strategies to promote and disseminate RBIE internationally and increase its impact have been performed. Such actions may help in the process of indexation of the RBIE journal on other places such as Web of Science and Scopus.

\section{The Three RBIE Issues from 2016}

On average, eleven manuscripts were published by issue on 2016. In the first issue (Vol. 24, No. 1, 2016), all published articles came from continuous flow (work submitted on regular basis with no specific call), while in the second issue (Vol. 24, No. 2, 2016) three of the articles came from continuous flow, seven from extended versions of awarded work published in the IV Brazilian Congress on Computers in Education (CBIE 2015 - IV Congresso Brasileiro de Informática na Educação) and one invited article from the panel "Policy and Guidelines for Informatics in Education: Innovation and Creativity in Basic Education" (presented at CBIE 2015). This third issue (Vol. 24, No. 3, 2016) is composed of ten articles, half from RBIE continuous flow and half extended versions of awarded work published in CBIE 2015.

Over 130 papers were submitted to RBIE in 2016 and the acceptance rate is approx. $25 \%$.

The number of registered users in the RBIE site is 1,921, from which 332 were registered in 2016.

Editor-in-chief

Dr. Sean Wolfgand Matsui Siqueira, Universidade Federal do Estado do Rio de Janeiro (UNIRIO), Brazil

Associate Editors

Dr. Bernardo Pereira Nunes, Pontifícia Universidade Católica do Rio de Janeiro (PUC-Rio) / Universidade Federal do Estado do Rio de Janeiro (UNIRIO), Brazil

Dr. Cristian Cechinel, Universidade Federal de Pelotas (UFPel), Brazil Dr. Miltiades Demetrios Lytras, The American College of Greece, Greece Dr. Patrícia Augustin Jaques, Universidade do Vale do Rio dos Sinos (UNISINOS), Brazil

Dr. Roberto Pereira, Universidade Federal do Paraná (UFPR), Brazil Dr. Wolfgang Nejdl, Leibniz Universität Hannover, Germany Dr. Xavier Ochoa, Escuela Superior Politécnica del Litoral (ESPOL), Ecuador 


\section{Acknowledgement}

We would like to thank all the authors that submitted their work to the Brazilian Journal of Computers in Education (RBIE - Revista Brasileira de Informática na Educação). Only with their contribution, submitting high quality manuscripts, it is possible to build a stronger research community on Computers in Education and improve the RBIE journal. Thank you very much for making this journal a target for your publications!

Special thanks also to all 210 reviewers, which contributed to the improvement of the manuscripts, providing valuable feedback to the authors and helping to support the journal and the Brazilian research community on Computers in Education. Through their detailed reading and kind contribution, it was possible to decide on the manuscripts that were ready for publishing in the journal.

RBIE editorial team

Here we present the list of RBIE reviewers that contributed from August 2015 to February 2017:

Adriana Justin Cerveira Kampff

Alessandro Arpetti

Alex Sandro Gomes

Alexandre Brandão

Alexandre Direne

Alisson Vasconcelos Brito

Amanda Meincke Melo

Ana Loureiro

Ana Maria Pereira Cardoso

Ana Paula Silva Figueiredo

Anamelea de Campos Pinto

Anarosa Brandão

André Brandão

Andre Constantino da Silva

André Fabiano de Moraes

André Grégio

André Pimenta Freire

André Raabe

André Santanchè

Andréia Miranda Domingues

Andrey Ricardo Pimentel

Anita Maria da Rocha Fernandes

Antonio Silva Sprock

Araci Hack Catapan

Artur Henrique Kronbauer

Arturo Hernández Domínguez

Beatriz Stransky Ferreira

Beatriz Wilges

Bernardo Pereira Nunes

Bruno Galasso
Bruno Silva Leite

Cabral LIMA

Carla Lopes Rodriguez

Carlo Barreto de Almeida

Caroline Kraus Luvizotto

Christian Puhlmann Brackmann

Christiane Gresse von Wangenheim

Claudia Rizzi

Clevi Elena Rapkiewicz

Clodis Boscarioli

Crediné Silva de Menezes

Cristian Cechinel

Daniel Augusto Couto Barone

Daniel Fábio Salvador

Daniela Trevisan

Danielo Gonçalves Gomes

Danilo Rodrigues César

Davide Taibi

Davidson Cury

Debora Barbosa

Denise Filippo

Denys Fellipe Souza Rocha

Diana Francisca Adamatti

Dinani Amorim

Donizetti F. Louro

Ecivaldo de Souza Matos

Edilene Ropoli

Edilson Ferneda

Edirlei Lima

Edson Pimentel 
List of RBIE reviewers that contributed from August 2015 to February 2017 (cont.):

Eduardo Aranha

Eduardo Barrére

Elaine Cristina Saito Hayashi

Elisa Boff

Eliseu Raphael Venturi

Ellen Francine Barbosa

Eráclito de Souza Argolo

Erico Marcelo Hoff do Amaral

Evandro Costa

Evandro Miletto

Everton José Goldoni Estevam

Fabiano Azevedo Dorça

Fábio Ferrentini Sampaio

Fabio José Parreira

Fernanda Campos

Fernanda Maria Pereira Freire

Fernando Andrade

Fernando Marques Filho

Flávia Maria Santoro

Francisco Milton Mendes Neto

Gabriel Arcanjo Santos de Albuquerque

Germana Nóbrega

Gianna Roque

Gilda Helena Bernardino

Giliane Bernardi

Giseli Rabello Lopes

Heitor Augustus Xavier Costa

Ibsen Mateus Bittencourt

Ines Messias

Isabel Dillmann Nunes

Isabela Gasparini

Ismar Frango Silveira

Ivana Marenzi

Jacques Duílio Brancher

João Carlos Gluz

José Aires de Castro Filho

José António Marques Moreira

José Geraldo Ribeiro Júnior

José Maria David

José Otavio Pompeu e Silva

José Parente Oliveira

José Wilker Silva

Júlia Marques Carvalho da Silva

Juliana Braga

Katia Morosov

Leandro Krug Wives

Leonardo Cunha de Miranda
Leonelo Dell Anhol Almeida

Leônidas de Oliveira Brandão

Letícia Capelão de Souza

Lilia Maria S Barreto

Liliana Passerino

Liliane dos Santos Machado

Lizandra Brasil Estabel

Lourenço de Oliveira Basso

Lucia Giraffa

Luciana A M Zaina

Luciana Bolan Frigo

Luciana de Lima

Luciano Soares Pedroso

Lucila Ishitani

Luis Paulo Leopoldo Mercado

Luiz Andre P Paes Leme

Luiz Melo Romão

Magalí Teresinha Longhi

Magda Bercht

Mara Lucia Fernandes Carneiro

Marcelo da Silva Hounsell

Marcelo D'Aquino Rosa

Marcelo Mendonça Teixeira

Marcelo Souza Motta

Márcia Cristina Moraes

Márcia Gonçalves de Oliveira

Márcia Rodrigues Notare

Marcos Alexandre de Melo Barros

Marcos Alexandre Rose Silva

Marcos Augusto Francisco Borges

Marcos da Fonseca Elia

Marcus Basso

Maria Almeida

Maria Angelica Penatti Pipitone

Maria Biasuz

Maria Candida Muller

Maria Claudia Brito

Maria de Fátima de Lima das Chagas

Maria Elizabeth Sucupira Furtado

Maria Helena Lima Baptista Braz

Maria Lucia Pozzatti Flôres

Mariano Pimentel

Marília Abrahão Amaral

Marilia Amaral

Mark Joselli

Marta Rosecler Bez

Maurício Massaru Arimoto 
List of RBIE reviewers that contributed from August 2015 to February 2017 (cont.):

Mauro Cavalcante Pequeno

Neide dos Santos

Nizam Omar

Nukácia Meyre Silva Araújo

Orivaldo de Lira Tavares

Patrícia Augustin Jaques

Patrícia B. Scherer Bassani

Patricia Jantsch Fiuza

Patrick Brito

Paulo César dos Santos

Paulo Henrique Lopes Aguiar

Pollyana Mustaro

Priscyla Waleska T. de Azevedo Simões

Rafaela Campos

Raymundo Carlos Machado Ferreira Filho

Rejane Frozza

Ricardo Azambuja Silveira

Ricardo José dos Santos Barcelos

Ricardo José Rocha Amorim

Ricardo Kawase

Ricardo Matsumura Araujo

Ricardo Ramos Fragelli

Roberto Almeida Bittencourt

Roberto Pereira

Roberto Romani

Rodolfo Ferreira Resende

Rodrigo Bonacin

Romero Tori

Rommel Wladimir de Lima
Ronaldo Ribeiro Goldschmidt

Rosa Maria Costa

Roseli Zen Cerny

Sandro da Silva Camargo

Sandro José Rigo

Sean Wolfgand Matsui Siqueira

Seiji Isotani

Sérgio Crespo

Sergio Serra

Sergio Teixeira de Carvalho

Silvia Dotta

Silvio Cesar Cazella

Simone Bicca Charczuk

Sonia Cristina Vermelho

Sonia Maria Costa Mendes

Soraia Silva Prietch

Stela Conceição Bertholo Piconez

Stella Maria Peixoto de A. Pedrosa

Taciana Pontual da Rocha Falcão

Taffarel Brant-Ribeiro

Tatiana Lebedeff

Teófilo Galvão Filho

Tiago Silva da Silva

Valéria Farinazzo Martins

Vanessa Luiza Tuono Jardim

Victor Stroele

Walter Ruben Iriondo Otero

Wilson Castello Branco Neto 